10. Про Вищий антикорупційний суд: Закон України від 7 червня 2018 р. Відомості Верховної Ради Украӥни. 2018. № 24. Ст. 212.

11. Рішення Касаційного адміністративного суду у складі Верховного Суду від 17 квітня 2019 p. у справі №9901/85/19. Сдиний державний реєстр судових рімень. URL: http://reyestr.court.gov.ua/Review/81366535 (дата звернення: 01.10.2019 p.).

12. Бангалорські принципи поведінки суддів від 19 травня 2006 р.: Схвалено Резолюцією Економічної та Соціальної Ради ООН 27 липня 2006 р. № 2006/23. Офіиійний веб-портал Верховної Ради Украӥни. URL: http://zakon2.rada.gov.ua/laws/show/995_j67 (дата звернення: 10.10.2019р.).

13. Стали відомі індикатори визначення невідповідності суддів критеріям доброчесності. Судебно-юридическая газета. URL: https://sud.ua/ru/news/sud-info/132839-stali-vidomi-indikatoriviznachennya-nevidpovidnosti-suddiv-kriteriyam-dobrochesnosti (дата звернення: 01.11.2019р.).

14. Рішення Касаційного адміністративного суду у складі Верховного Суду від 11 липня 2019 p. у справі №П/9901/246/19. Соиний державний реєстр судових рімень. URL: http://reyestr.court.gov.ua/Review/83070061

15. Про доступ до публічної інформації: Закон України від 13 січня 2011 р. № 2939-VI. Відомості Верховної Ради України. 2011. № 32. Ст. 314. (Із змінами).

16. Регламент Вищої кваліфікаційної комісії суддів України від 13 жовтня 2016 р. № 81/зП-16 (зі змін.). URL: https://vkksu.gov.ua/ua/about/reglament-vkks-ukraini/ (дата звернення: 10.10 .2019 р.).

DOI 10.31558/2518-7953.2019.2.7

УДК 342.32

I. B. Idecic,
асистент кафедри міжнародного
та європейського права
Національного університету
«Одеська юридична академія»,
кандидат юридичних наук

\title{
СТАТУТИ ТЕРИТОРІАЛЬНИХ ГРОМАД МІСТ: ДОСВІД ЗАСТОСУВАННЯ В УКРАЇНІ ЄВРОПЕЙСЬКИХ МУНІЦИПАЛЬНИХ СТАНДАРТІВ
}

Ключові слова: статут територіальної громади, територіальна громада, місцеве самоврядування, муніщципальне управління, хартія, європейські муніципальні стандарти.

Президент України підкреслив, що у його діяльності чільне місце посідатиме проведення чергового етапу муніципальної реформи в Україні, спрямованого на іiї остаточне завершення. Ця реформа триває від часу проголошення незалежності України, а тому потребує якнайшвидшого логічного завершення. Відповідно, актуальними $є$ наукові розробки у цьому напрямі, які сприятимуть як пошуку нових ідей для завершення реформи, так і підвищенню ефективності правотворчості у відповідній сфері. 
Тривала реалізація муніципальної реформи в Україні обумовила пильну увагу до ії основних етапів значної кількості вчених. Зокрема про цю реформу та про ії перші етапи активно писали М. П. Орзіх, В. Ф. Погорілко, О. Ф. Фрицький. Більш сучасні етапи реформи активно аналізували М. О. Баймуратов, Б. В. Калиновський, П. М. Любченко та інші вчені. Однак, майже завжди поза увагою вчених залишалися питання статутів територіальних громад загалом та відповідності статутів територіальних громад європейським стандартам зокрема. Серед дослідників, які найбільш активно аналізували це питання, варто назвати О. В. Батанова [1] та Н. В. Мішину [2; 3]. Однак, висновкам та пропозиціям цих авторів 3 аналізованого питання бракує системності, вони аналізували лише окремі аспекти проблеми. А тому доцільно продовжувати дослідження у цьому напрямі.

Метою статті є узагальнення українського досвіду правотворчості щодо статутів територіальних громад у контексті європейських муніципальних стандартів.

Європейська хартія місцевого самоврядування піднімає цікаве питання доречності державної реєстрації статутів територіальних громад в Україні. Проблема полягає ось у чому.

Хоча Свропейська хартія місцевого самоврядування прямо не передбачає обов'язкову наявність статуту територіальної громади та взагалі не згадує про такий вид нормативно-правового акту, одна зі статей Хартії - стаття «Конституційна та правова основа місцевого самоврядування» - передбачає, що «Принцип місцевого самоврядування визнається в національному законодавстві та, у міру можливості, в конституції», а стаття «Адміністративний нагляд за діяльністю органів місцевого самоврядування» встановлює, що:

«1. Будь-який адміністративний нагляд за органами місцевого самоврядування може здійснюватися тільки згідно з процедурами та у випадках, передбачених конституцією або законом.

2. Будь-який адміністративний нагляд за діяльністю органів місцевого самоврядування, як правило, має на меті тільки забезпечення дотримання закону та конституційних принципів. Однак вищі інстанції можуть здійснювати адміністративний нагляд за належністю виконання завдань, доручених органам місцевого самоврядування.

3. Адміністративний нагляд за органами місцевого самоврядування здійснюється у такий спосіб, щоб забезпечити домірність заходів контролюючого органу важливості інтересів, які він має намір охороняти».

Одним з проявів адміністративного нагляду за органами місцевого самоврядування в Україні варто вважати державну реєстрацію статутів територіальних громад.

Після того, як статут територіальної громади прийнято, його необхідно зареєструвати. Наразі ч. 2 ст. 19 Закону «Про місцеве самоврядування в Україні» 
зазначає про необхідність здійснити державну реєстрацію статуту територіальної громади у центральному органі виконавчої влади, прямо не визначаючи, щоправда, у якому. Зазначено лише, що такий орган «реалізує державну політику у сфері державної реєстрації (легалізації) об'єднань громадян, інших громадських формувань». Ще одна норма про державну реєстрацію статутів територіальних громад міститься у цитованій статті Закону «Про місцеве самоврядування в Україні», але у ч. 3. Цим нормативним положенням передбачено, що державна реєстрація передбачає перевірку документів, поданих у відповідний центральний орган виконавчої влади, та він може або здійснити іiі, або відмовити у іï здійсненні. Закон «Про місцеве самоврядування в Україні» містить таку підставу для відмови: «невідповідність Конституції та законам України», водночас встановлюючи можливість судового оскарження цієї відмови.

Очевидно, що цих нормативних положень недостатньо як для формування пакету документів для подання статуту територіальної громади на державну реєстрацію, так і для прийняття рішення про іiі здійснення або про відмову в реєстраційних діях. Деталізація відповідних норм Закону «Про місцеве самоврядування в Україні» здійснена у нормах Положення про державну реєстрацію статутів територіальних громад (затверджене постановою Кабінету Міністрів України від 27 липня 1998 р. № 1150).

Для дослідження мають значення такі нормативні положення цього документу:

- державна реєстрація усіх статутів територіальних громад сіл, селищ, міст, крім статутів територіальних громад міста Києва, міста Севастополя та усіх міст обласного значення покладається на районні, міськрайонні управління юстиції;

- державна реєстрація статуту територіальної громади міста Києва здійснюється Укрдержреєстром, а державна реєстрація статутів територіальних громад міста Севастополя і міст обласного значення покладається на відповідні міські управління юстиції;

- для державної реєстрації статуту необхідно подати такі документи: текст статуту територіальної громади; рішення місцевої ради щодо його затвердження; протокол пленарного засідання місцевої ради про реєстрацію статуту; підтвердження оплати реєстраційних дій.

Варто підкреслити, що сама заява про державну реєстрацію статуту територіальної громади має бути розглянута у місячний термін. За підсумками їі розгляду може бути прийнято одно з двох можливих рішень.

Найчастіше приймається позитивне рішення - рішення про державну реєстрацію статуту територіальної громади. У такому випадку видається свідоцтво про державну реєстрацію статуту територіальної громади встановленого зразка.

Окрім відмови у державній реєстрації статуту територіальної громади, чинне законодавство України передбачає також і можливість скасування реєстрації 
статуту. Воно здійснюється органом, що зареєстрував статут, у таких випадках: при поданні письмової заяви про це сільського, селищного, міського голови за наявності відповідного рішення представницького органу місцевого самоврядування або за рішенням суду.

Вчені вкрай рідко досліджують проблематику державної реєстрації статутів територіальних громад. Одним із винятків можна назвати статтю О. В. Батанова, який як висновок сформулював: «статут територіальної громади підлягає державній реєстрації в органах Міністерства юстиції України, яка, враховуючи природно-правовий характер місцевого самоврядування, на нашу думку, все ж таки має проводитися безоплатно» [1, с. 39].

Варто підкреслити справедливість того, що плата за державну реєстрацію статутів територіальних громад не має стягуватися. Однак, потрібно йти далі та впровадити положення, відповідно до якого статути територіальних громад взагалі не підлягатимуть державній реєстрації, що відповідатиме Свропейській хартії, процитованій вище.

Стосовно державної реєстрації статутів територіальних громад прослідковуються такі тенденції.

Перша тенденція обумовлена назвою цього акту - «статут». В Україні на підставі статутів функціонує низка видів юридичних осіб, переважно публічного права, зокрема товариства. Ст. 87 Цивільного кодексу України передбачає, що «установчим документом товариства $є$ затверджений учасниками статут або засновницький договір між учасниками, якщо інше не встановлено законом».

Саме статут підлягає державній реєстрації (так само, як і статут громади до набуття ним чинності). Порядок, відповідно до якого здійснюється державна реєстрація для цих статутів, має загальний характер, тобто є аналогічним порядку реєстрації статутів усіх юридичних осіб.

Друга тенденція полягає у тому, що статут територіальної громади - це підзаконний нормативно-правовий акт. В Україні здійснюється державна реєстрація значної кількості підзаконних нормативно-правових актів (Указ Президента України від 3 жовтня 1992 р. «Про державну реєстрацію нормативно-правових актів міністерств та інших органів виконавчої влади» та Положення про державну реєстрацію нормативно-правових актів міністерств, інших органів виконавчої влади, затверджене Постановою Кабінету Міністрів України від 28 грудня 1992 р.).

Ознайомлення $з$ положеннями цих документів надає підстави стверджувати, що державна реєстрація статутів територіальних громад здійснюється за процедурою, подібною до державної реєстрації статутів юридичних осіб (точніше юридичних осіб публічного права), а не подібною до процедури державної реєстрації нормативно-правових актів. Крім того, не встановлено вимог щодо державної реєстрації актів органів місцевого самоврядування - тільки вимоги щодо від- 
повідної реєстрації деяких актів органів виконавчої влади. Не вимагається здійснення державної реєстрації і актів представницьких органів (крім того, в Україні немає іншого, ніж статут територіальної громади, нормативно-правового акта 3 назвою «статут»).

Саме з огляду на це і запропоновано скасувати державну реєстрацію статутів територіальних громад. Адже ці статути приймаються представницькими органами місцевого самоврядування, так само як і інші акти, а отже - щодо них треба застосувати положення ч. 2 ст. 144 Конституції України («рішення органів місцевого самоврядування з мотивів їхньої невідповідності Конституції чи законам України зупиняються у встановленому законом порядку з одночасним зверненням до суду» [4]).

Наявність чи відсутність державної реєстрації статутів територіальних громад загалом та статутів територіальних громад міст зокрема також має відношення до проблеми їхньої юридичної сили.

У юридичній літературі сформувалася одностайна думка щодо того, що положенням конституції притаманна найвища юридична сила. Основний Закон України 1996 р. не є винятком. Відповідно до п. 2 ст. 8 «Конституція України має найвищу юридичну силу. Закони та інші нормативно-правові акти приймаються на основі Конституції України і повинні відповідати їй» [4].

Щодо юридичної сили статутів територіальних громад варто підкреслити, що одностайності серед вчених не спостерігається. Якщо звернутися до чинного законодавства України, то у ньому передбачено лише, що статут територіальної громади в Україні затверджується рішенням представницького органу - відповідної місцевої ради. Положення про юридичну силу статутів територіальних громад не містять Конституція України, Закон «Про місцеве самоврядування в Україні», інші акти. А отже, презюмується: його юридична сила аналогічна юридичній силі інших актів міських рад.

У зарубіжній практиці є приклади, коли статутам територіальних громад притаманна найвища юридична сила серед інших актів муніципального законодавства. Але навіть з урахуванням цього навряд чи буде правильним зауваження С. Г. Соловйова про те, що «статут муніципального утворення має значну муніципальну юридичну силу» [5, с. 25]. Словосполучення «муніципальна юридична сила» навряд чи можна визначити як коректне, так само як і спробу охарактеризувати юридичну силу не як «найвищу», а як «значну».

Окрім ознаки «вища юридична сила» конституціям притаманна така ознака, як застосування їхніх положень як фундаменту, підгрунтя нормотворчості. Дослідники стверджують: «зустрічаються твердження про те, що конституція є фундаментом законотворчості. Це визначення синонімічне визначенню «вища юридична сила». Фундамент - та основа, на якій грунтується будівля. У даному ви- 
падку конституція є основою, на якій грунтується система законодавства» [6, c. 34]. Основний Закон України 1996 р. традиційно розглядається як фундамент національного законодавства. Значна частина іiі статей містить відсильні положення, у яких йдеться про те, що те чи інше положення має бути деталізовано у поточному законодавстві.

Такі відсилання передбачено і у положеннях про місцеве самоврядування. Наприклад, у Розділі ХІ «Місцеве самоврядування» встановлено, що «Особливості здійснення місцевого самоврядування в містах Києві та Севастополі визначаються окремими законами України» (ч. 2 ст. 140) та що «статус голів, депутатів і виконавчих органів ради та їхні повноваження, порядок утворення, реорганізації, ліквідації визначаються законом» (ч. 4 ст. 141) [4]. У цьому Розділі є й інші відсильні норми.

Деякі вчені визнають цю ознаку і за статутами територіальних громад як за місцевими конституціями. О. С. Шугріна пише, що «статут - це основа для нормотворчості» [7, с. 80-81]. Варто зазначити, що вона аналізує законодавство іншої країни, у якій статутам притаманна вища юридична сила (зрозуміло, на місцевому рівні). Для України ця теза поки що не є справедливою.

Отже, навряд чи сучасні статути територіальних громад наразі можна вважати фундаментами законотворчості. Але цей підхід є перспективним, і може бути втілений на наступних етапах муніципальної реформи.

Окрім Конституції України, фундаментом муніципального права є Закон «Про місцеве самоврядування в Україні», але не статути територіальних громад. Ця теза сформульована на підставі положень цього Закону, якими передбачено: статутом територіальної громади визначаються:

- порядок проведення загальних зборів громадян за місцем проживання;

- порядок внесення місцевої ініціативи на розгляд місцевої ради;

- порядок обнародування рішення місцевих рад, прийнятого з питання, внесеного на їі розгляд шляхом місцевої ініціативи;

- порядок формування та організація діяльності рад;

- порядок організації громадських слухань.

Отже, статут територіальної громади навряд чи може виступати підгрунтям нормотворчості, навіть місцевої нормотворчості.

Варто підкреслити: Закон «Про місцеве самоврядування в Україні» містить ст. 19 «Статут територіальної громади села, селища, міста». Треба зазначити, що більш логічним вбачається їі розташування в Законі не після згадки про статути територіальних громад у статтях про проведення загальних зборів громадян за місцем проживання, порядок внесення місцевої ініціативи на розгляд місцевої ради, порядок обнародування рішення місцевих рад, прийнятого з питання, внесеного на їі розгляд шляхом місцевої ініціативи, порядок формування та органі- 
зація діяльності рад та порядку організації громадських слухань, а перед цими статтями.

Отже, статтю «Статут територіальної громади села, селища, міста» Закону «Про місцеве самоврядування в Україні» можна рекомендувати зробити ст. 6-1. Розміщення статті «Статут територіальної громади села, селища, міста» після ст. 6 «Територіальна громада»є більш логічним.

Продовжуючи питання про юридичну силу статутів територіальних громад, аналіз цих статутів демонструє, що самі вони містять інформацію про свою юридичну силу, і не завжди ці положення є коректними. Статут територіальної громади м. Одеси проголошує: «Статут є актом прямої дії» [8]. Відповідно до іншої статті цього Статуту, «в систему місцевих нормативно-правових актів входять:

- Статут міської громади;

- рішення місцевого референдуму нормативно-правового характеру;

- рішення міської ради нормативно-правового характеру;

- розпорядження міського голови нормативно-правового характеру;

- рішення виконавчого комітету міської ради нормативно-правового характеру;

- розпорядження голів районних адміністрацій та акти інших керівників виконавчих органів міської ради нормативно-правового характеру» [8].

Статут територіальної громади міста Коростень вміщує положення про те, що «Статут Коростеня має найвищу юридичну силу щодо актів, які приймаються в системі місцевого самоврядування міста, за винятком рішень, прийнятих місцевим референдумом» [9]. Статут територіальної громади міста Бердянська прямо передбачає, що він «має найвищу юридичну силу відносно актів, які приймаються в системі місцевого самоврядування за винятком рішень, прийнятих місцевим референдумом» [10].

Привертає увагу і Статут територіальної громади міста Лозова. Він проголошує: «статут є актом прямої дії і має вищу юридичну силу в системі нормативно-правових актів міської влади на території міста Лозова» [11]. Статут територіальної громади міста Чугуєва передбачає: «Статут діє на території міста та має вищу юридичну силу стосовно інших актів органів і посадових осіб місцевого самоврядування» [12]. Отже, означена проблема потребує визначення та надає перспективи для подальших творчих розвідок у цьому напрямі.

Висновок. Статут територіальної громади міста - иее підзаконний нормативно-правовий акт, щуо ухвалюється міською радою для врахування історичних, національно-культурних, сочіально-економічних та інших особливостей міського самоврядування й регламентачзї колективної участі членів територіальної громади у його здійсненні. Іменувати статути територіальних громад міст «міськими конституціями», як ие часто трапляється в літературі, навряд чи справедливо. Конституція Украӥни та статути територіальних громад укра- 
їньких міст мають такі спільні ознаки формального характеру, як юридична техніка та тезаурус, а також відсутність закріпленого нормативними актами порядку їхньої розробки та ухвалення. Більшість формальних ознак статутів територіальних громад міст не збігається з формальними ознаками Основного закону, зокрема обов'язковість наявності, необхідність державної реєстрації, найвища юридична сила та здатність виступати фундаментом для подальшої нормотворчості, пряма дія, стабільність. Уважати статут територіальної громади міста «міською конституцуією» навряд чи можливо з урахуванням сучасних європейських муніципальних стандартів.

1. Батанов О. В. Питання розробки та прийняття статуту територіальної громади. Юридичний журнал. 2004. № 3. С. 38-40.

2. Мішина Н. В. Муніципальна реформа в Україні: стан і перспективи. Право України. 2018. № 4. C. 126-138.

3. Mishyna N. V. Local Government and the Doctrine of Separation of Powers. Юридический вестник. 2004. № 4. С. 100-103.

4. Конституція України від 28 червня 1996 р. Відомості Верховної Ради Украӥни. 1996. № 30. Ст. 142.

5. Соловьев С. Г. Муниципальное право России: учебник. Москва: ИНФРА-М, 2013. 312 с.

6. Конституционное право зарубежных стран: учебник для студентов вузов/ под ред. В. О. Лучина, Г. А. Василевича, А. С. Прудникова. Москва: ЮНИТИ-ДАНА: Закон и право, 2012. $727 \mathrm{c}$.

7. Шугрина Е. С. Муниципальное право: учебник. Москва: Норма: Инфра-М, 2012. 560 с.

8. Статут територіальної громади міста Одеса. URL: http://www.omr.gov.ua/images/File/ Ustav/1240_Ustav.doc

9. Статут територіальної громади міста Коростень. URL: http://www.korosten.in.ua/index. php?page $=206$

10. Статут територіальної громади м. Бердянська. URL: http://kurort-berdyansk.com/statutteritorialnoyi-gromadi.html stgml.html

11. Статут територіальної громади міста Лозова. URL: http://www.lozovarada.gov.ua/ $\mathrm{id}=1127$

12. Статут територіальної громади міста Чугуєва. URL: http://chuguev-rada.gov.ua/?page_ 